\title{
The Role of Helicobacter Pylori in Chronic Tonsillitis
}

\author{
Ahmed Abdel Aziz* \\ Department of ENT, El Minia University Hospital, Egypt
}

*Corresponding author: Ahmed Abdel Aziz, Department of ENT, El Minia University

Hospital, Egypt, Email: ahmed_ent77@yahoo.com

\section{Research Article}

Volume 3 Issue 1

Received Date: June 11, 2018

Published Date: June 22, 2018

DOI: $10.23880 / 00 A J-16000170$

\section{Abstract}

Chronic tonsillitis is a common disease and bacterial infection is usually the cause. Helicobacter pylori were identified in core and surface of tonsillar tissue. The transmission of Helicobacter pylori organism to the tonsillar tissue is not yet understood.

Keywords: Helicobacter Pylori; Chronic Tonsillitis

\section{Introduction}

Chronic tonsillitis is a common disease and bacterial infection is usually the cause [1]. Helicobacter pylori were identified in core and surface of tonsillar tissue [2]. The transmission of Helicobacter pylori organism to the tonsillar tissue is not yet understood [3]. The role of this study is to clarify whether Helicobacter pylori may take place in the etiology of chronic tonsillitis.

\section{Patient and Method}

This cross-sectional prospective study was conducted on 50 children scheduled for tonsillectomy with or without adenoidectomy in the Department of Otorhinolaryngology, EL Minia University Hospital from May 2016 to June 2017 with age ranges from 3-15 with 23 were male and 27 were female.

\section{Inclusion Criteria}

a) All children with chronic recurrent tonsillitis.

b) Patients whom guardians gave consent. c) Patients underwent elective tonsillectomy for chronic recurrent tonsillitis.

\section{Exclusion Criteria}

a) All patient on proton pump inhibitor one month preoperative.

b) ALL immune compromised patient.

c) The all patient underwent adenotonsillectomy for obstructive sleep apnea.

d) Patients who declined to participate in the study.

The tonsillectomy was done under general anaesthesia by a classical. Dissection and ligation technique and the adenoid (if enlarged) was curetted by an adenoid curette. After surgical resection, one randomly selected tonsil was chosen to provide for the tonsillar specimen material from each patient. The surgical specimens were kept at room temperature and at the end of the operation each tonsil was divided with a sterile blade into two parts: one to subjected to rapid urease test (RUT) and the other to be used for histopathological examination. A core biopsy 


\section{Otolaryngology Open Access Journal}

(containing about 3-4 $\mathrm{mm}$ diameter) sample was then taken from each part.

\section{Rapid Urease Test (RUT)}

It is a qualitative assay based on the detection of urease, produced by H. pylori. The test system consists of a test will be filled with a urea containing gel. Sample of the tonsil were inoculated into the RUT test. The test was considered positive when the color changed from yellow to orange or red within 24 hours.

\section{Histopathological Examination}

Tissue sections from studied cases were fixed in $10 \%$ neutral buffered formalin processed and embedded in parrafain wax. Five micro millimeter sections were prepared and stained with haematoxylin and eosin for histopathological evaluation. H.pylori was dignosed when the characteristic curved organism visualized in a tonsillar tissue biopsy speciemen.

The study was conducted according to the Declaration of Helsinki and was approved by Minia faculty of Medicine institutional review board. An informed written consent in accordance with Minia University Ethical Committee guidelines was taken from guardians of all cases.

\section{Results}

This study is a descriptive cross-sectional study that was carried on fifty (50) patients who were presented to the outpatient clinic of ENT department in Minia University hospital. The patient's age range was between 3 to 15 years with a mean of $5.6 \pm 2.1$ Twenty- three of the studied patients were male (46\%) and twenty -seven was female $(54 \%)$. Forty patients(80\%) were rural and ten patients(20\%) were urban.

$56 \%$ of the studied patients werer positive rapid urease test and had $\mathrm{H}$ pylori in stool. $58 \%$ of the patients were histopatholodical positive and had H.pylori antigen in stool (Table 1).

\begin{tabular}{|c|c|c|c|}
\hline \multicolumn{2}{|c|}{} & Freq. & Percentage \\
\hline \multirow{2}{*}{ RUT } & Positive & 28 & $56 \%$ \\
\cline { 2 - 4 } & Negative & 22 & $44 \%$ \\
\hline \multirow{2}{*}{ Stool Test } & Positive & 29 & $58 \%$ \\
\cline { 2 - 4 } & Negative & 21 & $42 \%$ \\
\hline $\begin{array}{c}\text { Histopathologic } \\
\text { Examination }\end{array}$ & Positive & 29 & $58 \%$ \\
\cline { 2 - 4 } & Negative & 21 & $42 \%$ \\
\hline
\end{tabular}

Table 1: Detection of H.pyloriamong the studied patients.
Data were collected, revised, verified, coded, then entered PC for statistical analysis done by using SPSS statistical package version 20 .

\section{Discussion}

Chronic tonsillitis is a common disease in children .Its etiology is still unclear [4]. Helicobacter pylori (H.pylori) is spiral -shaped, gram- negative microorganism that mainly present in gastric mucosa [5]. The prevalence of the infection of H.pylori is higher in developing countries [6]. The exact route of transmission has not yet been proved, may be the fecal-oral route or oral-oral route [7]. Also, gastroesophageal reflux may be considering a route for transmission. The role of gastroesophageal reflux in the etiology of chronic tonsillitis is controversy [4]. Reflux of the gastric secretions, in infected H.pylori person, which contact with the areodigestive tract, may be responsible for chronic tonsillitis [8]. The recent methods of diagnosis of H.pylori infection can be classified as either invasive or non-invasive methods. The invasive methods include culture, biopsy, rapid urease test (RUT) and PCR. The non invasive methods include the stool antigen test, serum test, urea breath test and urinary antibody test. The current study compares with Abdel Monem, et al. Who was made study on prevalence of chronic recurrent tonsillitis and 53\% were found to be positive for H.pylori using RUT [9]. The overall prevalence rate was lower than our present study which was $65 \%$ were found to be positive for H.pylori using RUT. The difference in result may be due to the use of antimicrobial drugs and proton pump inhibitors which may result in false negative results as the author not mentioned it in inclusion criteria. Vayisoglu, et al. made a study to evaluate the relationship of chronic tonsillitis and H.pylori and they found that $\mathrm{H}$ pylori do not colonize in tonsillar tissue of patients with chronic tonsillitis. They used RUT and immunohistochemical tests [10]. Siupsinskiene, et al. compared $\mathrm{H}$ pylori infection in chronic tonsillitis patients and tonsillar hypertrophy patients with significantly higher in chronic tonsillitis group. Also, they found significant a correlation between positive H.pylori finding and signs of gastroesophageal reflux [11]. Güçlü, et al. used PCR and RUT on tonsillar tissue from patients complained with chronic tonsillitis and patients complained with hypertrophied tonsil and they found no significant difference between two group and also found low $\mathrm{H}$ pylori infection in both group [12]. But they did not mention that they used serological tests, stool antigen test or taking a biopsy from gastric mucosa to detect $\mathrm{H}$ pylori infection in these patients. There is not yet a single method considered a gold standard for detection $\mathrm{H}$ pylori but a combination of two or three methods to detect $\mathrm{H}$. 


\section{Otolaryngology Open Access Journal}

pylori. In current study, researchers were used three methods to detect $\mathrm{H}$ pylori. In the first method, stool antigen test was used to detect infection of the patients with H.pylori (58\% of patient were positive to H.pylori).

And 2 methods RUT and histopathological examination were used to detect H.pylori infection in tonsillar tissue (65\% was positive to RUT and $58 \%$ was positive to histopathological examination). Vilarino, et al. revealed that methods used for detecting H.Pylori in gastric mucosa is not adequate to detect infection in tonsillar tissue [13]. Researchers in current study think that variation of different studies to evaluate h.pylori colonization in tonsil are due to the absence of accurate evaluation of the patients to be infected with $\mathrm{H}$ pylori by stool antigen test or by taken biopsy from stomach as it represents current infection but some studies were used serological test alone which may give false results as antibodies remain in blood even after patient cure from infection. Also, researchers think that every study must include, inclusion criteria, that confirm these patients not received any medical treatment (antibiotics and proton pump) which may lead to decrease the number of H.pylori in tonsillar tissue and so detection of $\mathrm{H}$ pylori is difficult and false negative results will happen. Also, difference of the socioeconomic level of patient between different studies may be considering a cause of variation between results of different studies.

\section{References}

1. Najafipour R, Farivar TN, Pahlevan AA, Johari P, Safdarian F, et al. (2012) Agreement rate of rapid urease test, conventional PCR, and scorpion real time PCR in detecting helicobacter pylori from tonsillar samples of patients with chronic tonsillitis. J Glob Infect Dis 4(2): 106-109.

2. Khademi B, Niknejad N, Gandomi B, Yaganeh F (2007) Comparison of helicobacter pylori colonization on the tonsillar surface versus tonsillar core tissue as determined by the CLO test. Ear Nose Throat J 86(8): 498-501.

3. Azevedo N, Guimaraes N, Figueiredo C, Keevil C, Vieira M (2007) A new model for transmission of helicobacter pylori: role of environmental reservoirs as gene pool to increase stain diversity. Crit Rev Microbiol 33(3): 157-169.

4. Lukes P, Astl J, Pavlik E, Potuznikova B, Sterz l, et al. (2008) Helicobacter pylori in tonsillar and adenoid tissue and its possible role in oropharyngeal carcinogenesis. Folia Biol 54(2): 33-39.

5. Ochung'o OP, Mugwe P, Masinde P, Waweru W (2015) Prevalence of H.Pylori in tonsillar tissue of patients with chronic recurrent tonsillitis using Rapid Urease test in a tertiary referral hospital in sub Saharan Africa. Indian J Otolryngol Head Neck Surg 67(3): 223-226.

6. Nguyen AM, El-Zaatari FA, Graham DY (2000) Helicobacter pylori in the oral cavity. A critical review of the literature. Oral Surg Oral Med Oral Pathol Oral Radiol Endod 79(6): 705-709.

7. Eyigor M, Eyigor H, Gultekin B, Aydin N (2009) Detection of helicobacter pylori in adenotonsillar tissue specimens by rapid urease test and polymerase chain reaction. Eur Arch Otorhinolaryngol 266(10): 1611-1613.

8. Fancy T, Mathers PH, Ramadan HH (2009) Otitis media with effusion: a possible role for helicobacter pylori. Otolaryngol Head Neck Surg 140(2): 256-258.

9. Abdel-monem MH, Magdy EA, Nour YA, Harfoush RA, Ibreak A (2011) Detection of helicobacter pylori in adenotonsillar tissue of children with chronic adenotonsillitis using rapid urease test,PCR and blood serology: a prospective study. Int J Pediatr Otolaryngol 75(4): 568-572.

10. Vayisogulu Y, Ozcan C, Polat A, Delialioglu N, Gorur K (2008) Does helicobacter pylori play a role in the development of chronic adenotonsillitis? Int J Pediatr Otorrhinolaryngol 72(5): 1497-1501.

11. Siupsinskiene N, Katutiene I, Jouikiene V, Janciauskas D, Vaitkus S (2017) Helicobacter pylori in the tonsillar tissue: a possible association with chronic tonsillitis and laryngopharyngeal reflux. J Laryngol Otol 131(6): 549-556.

12. Güçlü O, Akcali A, Şahin EM, Tekin K, Bartuçu O, et al. (2013) Relationship between helicobacter pylori adenotonsillar colonization and frequency of adenotonsillitis in children. Balkan Med J 30(3): 301304.

13. Vilarhinho S, Guimaraes NM, Ferreira RM, Gomes B, Wen X, et al. (2010) Helicobacter pylori colonization of the adenotonsillar tissue: fact or fiction?. Int J Pediatr Otorhinolaryngol 74(7): 807-811. 